\title{
Analisis Evaluasi Kelayakan Bisnis di Katering Sarahfie
}

\author{
Farhan Ariestianto A, Dewi Turgarini, Agus Sudono \\ Manajemen Industri Katering, Fakultas Pendidikan Ilmu Pengetahuan Sosial, \\ Universitas Pendidikan Indonesia, Jl. Dr. Setiabudhi No. 229, Bandung 40154, Indonesia \\ * Koresponding Penulis. E-mail: farhanariestianto@student.upi.edu (Farhan \\ Ariestianto)
}

\begin{abstract}
Abstrak
Analisis Evaluasi Kelayakan Bisnis di Katering Sarahfie merupakan sebuah penelitian yang dilakukan atas dasar permasalahan mengenai penurunan penjualan yang berdampak pada hasil pendapatan perusahaan. Jenis penelitian yang digunakan adalah deskriptif dengan metode penelitian kualitatif dan kuantitatif (mix method research). Teknik pengumpulan data dilakukan melalui observasi, wawancara, studi dokumentasi, serta kuesioner. Teknik analisis data yang dilakukan meliputi analisis legalitas, analisis pasar, analisis pemasaran, analisis keuangan, analisis teknis/teknologi, analisis manajemen dan organisasi, analisis ekonomi dan sosial, serta analisis lingkungan hidup. Hasil penelitian ini menunjukan bahwa bisnis katering Sarahfie layak untuk diteruskan dan dikembangkan namun dengan perbaikan di beberapa aspek. Pada aspek legalitas, terdapat dokumen yang belum diperbaiki serta dilengkapi seperti bentuk badan usaha, tanda daftar perusahaan, nomor pokok wajib pajak, serta izin perusahaan. Lalu pada aspek pasar, perusahaan telah menetapkan pasar yang akan dimasuki dan peluang pasar yang ada, serta calon konsumen potensial. Kemudian pada aspek pemasaran dengan menggunakan metode penilaian bauran pemasaran (marketing mix 7P) yang dilakukan terhadap konsumen katering Sarahfie menunjukan hasil yang baik. Selanjutnya pada aspek keuangan yang dinilai berdasarkan perhitungan arus kas serta perhitungan penilaian investasi yaitu Net Present Value (NPV) memperoleh hasil yang positif atau lebih besar dari nol. Lebih lanjut pada aspek teknis/operasi, terdapat hal yang perlu diperbaiki seperti cara pengolahan makanan. Selain itu, pada aspek manajemen dan organisasi terdapat beberapa hal yang perlu diperbaiki seperti keterlambatan pemberian kompensasi, serta tidak adanya program pengembangan karir. Sedangkan pada aspek ekonomi dan sosial terdapat dampak negatif seperti mengganggu ketentraman warga sekitar serta terjadi perubahan sikap masyarakat setempat. Sementara itu, pada aspek lingkungan hidup tidak terdapat kerusakan lingkungan hidup di daerah sekitar perusahaan.
\end{abstract}

Kata Kunci: Analisis Evaluasi; Kelayakan Bisnis; Katering Sarahfie

\section{Pendahuluan}

Pariwisata adalah berbagai macam kegiatan wisata yang didukung dengan berbagai fasilitas serta layanan yang disediakan oleh masyarakat, pengusaha, Pemerintah, dan Pemerintah Daerah (Pasal 1 UU RI No.10 Tahun 2009 Tentang Kepariwisataan). Fasilitas dan layanan yang disediakan oleh masyarakat, pengusaha, Pemerintah dan Pemerintah Daerah ialah akomodasi, transportasi, makanan, rekreasi serta jasajasa lain yang terkait. Dewasa ini pariwisata merupakan sebuah kegiatan bisnis yang menguntungkan, karena pariwisata berorientasi pada penyediaan jasa yang dibutuhkan wisatawan.

Bagi Indonesia sendiri, sektor pariwisata merupakan salah satu sektor paling potensial dalam perkembangan pembangunan negara Indonesia. Sektor pariwisata telah berperan penting sebagai pendapatan negara (devisa) terbesar 
kedua setelah sektor migas, yang menjadi industri penting yang dapat diandalkan Pemerintah untuk pembangunan ekonomi nasional (PPRI No.50 Tahun 2011 Tentang rencana Induk Pembangunan Kepariwisataan Nasional Tahun 20102025). Pengelolaan pariwisata di Indonesia diatur, serta diawasi oleh Kementrian Pariwisata dan Ekonomi Kreatif.

Salah satu cara untuk menarik wisatawa ialah menyebarkan berita dari mulut ke mulut tentang kepuasan

konsumen yang bersangkutan dengan kegiatan atau pengalamannya di tempat wisata. Rata-rata wisatawan tertarik untuk mencari pengalaman baru tentang budaya dan tradisi suatu daerah tujuan wisata. Makanan, dan pariwisata memiliki hubungan yang erat satu sama lain dan makanan adalah sumber daya pariwisata yang penting. Pariwisata makanan merupakan kebutuhan dasar manusia yang harus dipenuhi. Makanan dapat berperan penting dalam kisah perjalanan wisatawan karena dengan makanan, wisatawan dapat mengetahui budaya daerah tertentu. Wisatawan yang mengkonsumsi makanan lokal dapat memahami identitas, dan etnis dari daerah tujuan wisata. Pengalaman makan dapat menggambarkan pengalaman budaya, status, dan identitas budaya. Kepulauan indonesia yang luas mengakibatkan beragamnya produkproduk makanan khas dari daerah tertentu, sehingga wisatawan memiliki berbagai macam pilihan untuk memilih makanan yang diinginkan. Oleh sebab itu, makanan Indonesia kini mulai menarik lebih banyak perhatian wisatawan Internasional maupun wisatawan domestik (Henderson, 2009) (Hendijani, 2016).

Industri kuliner merupakan salah satu bagian untuk menunjang perkembangan sektor pariwisata. Perkembangan industri kuliner saat ini bukan hanya sekedar pemenuhan akan kebutuhan dasar manusia saja namun telah menjadi gaya hidup di kalangan masyarakat modern. Di era modern ini, banyak masyarakat (wisatawan) yang sengaja datang ke daerah tujuan wisata hanya untuk menikmati makanan khas daerah tersebut. Oleh karena itu industri kuliner kini berkembang pesat dengan pola konsumsi (makanan) masyarakat yang berpikir praktis sehingga para pebisnis tertarik untuk membangun usaha kuliner berupa restoran, cafe, katering hingga street food. Maka dari itu industri kuliner menjadi salah satu aspek penting yang dapat mempengaruhi perkembangan sektor pariwisata.

Katering merupakan bagian dari industri kuliner yang bergerak dibidang pelayanan jasa makanan. Melihat peluang yang ada, kini para pebisnis banyak yang membuat usaha bisnis serupa. Namun dengan banyaknya peluang dalam bisnis ini tidak menjamin bahwa usaha bisnis yang dijalankan ini akan berhasil, karena dalam mencapai tujuan yang diharapkan oleh pebisnis (perusahaan) akan banyak sekali resiko dan hambatan yang harus dihadapi. Maka dari itu, faktor pengetahuan yang baik dari pebisnis (pemilik usaha) berperan penting dalam membuat kebijakan perencanaan usaha yang baik agar dapat diwujudkan secara nyata.

Bisnis katering di Kota Bandung kini telah menjamur bertebaran dimanamana. Jumlah katering di Kota Bandung mengalami peningkatan sebanyak $16 \%$ atau sebanyak 9 usaha katering dari tahun sebelumnya. Jelas bahwa saat ini bisnis katering sedang banyak digemari oleh para pebisnis di kota Bandung. Salah satu diantaranya ialah katering Sarahfie. Katering ini sudah bergerak sejak tahun 1997 dalam memenuhi pesanan pelanggannya. Berdasarkan informasi yang didapatkan dari ibu $\mathrm{Hj}$. Pipit Nurindah selaku pemilik Katering Sarahfie, dalam tiga tahun terakhir jumlah pemesanan dan pendapatan telah mengalami penurunan. Pada tahun 2015 katering Sarahfie mengalami penurunan 
jumlah pemesanan sebanyak 10 event dari tahun sebelumnya, dan pada tahun berikutnya terjadi penurunan pemesanan kembali sebanyak 10 event. Tentu saja penurunan jumlah pemesanan tersebut berdampak pada penurunan jumlah pendapatan yang diperoleh oleh pihak katering Sarahfie. Pada tahun 2014 Sarahfie mengalami penurunan pendapatan sebesar Rp. 554.000.000 atau $16,39 \%$ dari tahun sebelumnya. Sedangkan tahun berikutnya Sarahfie mengalami penurunan kembali yaitu sebesar Rp. 713.500.000 atau sama dengan 19,61\%.

Banyak kendala pada perusahaan Katering Sarahfie yang diprediksikan akan menghambat kelancaran produksi perusahaan, oleh karena itu studi kelayakan bisnis perlu dikaji secara mendalam berdasarkan semua aspek yang ada pada Studi Kelayakan Bisnis. Berdasarkan beberapa penjelasan di atas, perlu dikaji dan dirumuskan penelitian untuk mengetahui apakah bisnis katering Sarahfie ini layak atau tidak untuk dilanjutkan dan atau dikembangkan dengan judul Analisis Evaluasi Kelayakan Bisnis di Katering Sarahfie.

Berdasarkan latar belakang masalah maka perumusan masalahnya adalah:
a. Bagaimana gambaran usaha Katering Sarahfie ditinjau berdasarkan aspek legalitas?
b. Bagaimana gambaran usaha Katering Sarahfie ditinjau berdasarkan aspek pasar?
c. Bagaimana gambaran usaha Katering Sarahfie ditinjau berdasarkan aspek pemasaran?
d. Bagaimana gambaran usaha Katering Sarahfie ditinjau berdasarkan aspek keuangan?
e. Bagaimana gambaran usaha Katering Sarahfie ditinjau berdasarkan aspek teknis/operasi?
f. Bagaimana gambaran usaha Katering Sarahfie ditinjau

berdasarkan aspek manajemen dan organisasi?

g. Bagaimana gambaran usaha Katering Sarahfie ditinjau berdasarkan aspek ekonomi dan sosial?

h. Bagaimana gambaran usaha Katering Sarahfie ditinjau berdasarkan aspek lingkungan hidup?

i. Bagaimana kelayakan bisnis pada Katering Sarahfie?

\section{Metode Penelitian}

Penelitian dilakukan di industri rumahan yang dimiliki oleh ibu Hj Pipit Nurindah, bertempat di Ruko Metro Indah Mall blok H No.18 Bandung serta di Jalan Kencanawangi Utara No. 21 Bandung. Mengenai waktu penelitian dilakukan dalam kurun waktu kurang dari satu tahun (November-Agustus 2017).

Jenis penelitian yang dilakukan adalah penilitian deskriptif dan menggunakan metode penelitian gabungan (mix method research) dengan strategi transformatif sekuensial yakni proses penggabungan data dari dua tahap pengumpulan data (kualitatif dan kuantitatif) untuk mengetahui bagaimana kelayakan katering Sarahfie (Yusuf, 2015:437).

Analisis data kualitatif digunakan untuk mengetahui bagaimana gambaran katering Sarahfie berdasarkan pada aspek legalitas, pasar, teknik/operasi, manajemen dan organisasi, ekonomi dan sosial, serta lingkungan hidup. Sedangkan analisis data kuantitatif digunakan untuk mengetahui bagaimana gambaran katering Sarahfie berdasarkan pada aspek pemasaran dan keuangan.

Populasi dalam penelitian ini adalah seluruh konsumen yang telah menggunakan produk (barang dan jasa) katering Sarahfie selama 1 (satu) tahun terakhir. Jumlah konsumen katering Sarahfie selama tahun terakhir (2016) adalah sebanyak 41 orang. Ukuran sampel konsumen katering Sarahfie 
sebanyak 37,19 atau dibulatkan menjadi 38 orang responden penelitian.

Teknik pengumpulan data yang digunakan pada penelitian gabungan (mix method research) ini ialah observasi, wawancara, studi dokumentasi, kuesioner. Pada penelitian ini, uji keabsahan data untuk data kualitatif menggunakan uji kredibilitas data. Uji kredibilitas merupakan proses pengujian data yang dilakukan untuk mengetahui nilai kebenaran data melalui beberapa teknis. Uji kredibilitas dilakukan dengan cara perpanjangan pengamatan, peningkatan ketekunan, trianggulasi, analisis kasus negatif, dan member check (Sugiyono, 2013:460). Sedangkan uji keabsahan data untuk data kuantitatif menggunakan uji validitas dan reliabilitas.

Menurut Arikunto (2013:211) validitas adalah suatu ukuran yang menunjukkan tingkat- tingkat kevalidan atau kesahihan suatu instrumen. Suatu instrumen dinyatakan valid dan sahih apabila validitasnya tinggi. Dalam pengujian validitas penelitian ini, peneliti menggunakan aplikasi SPSS 22 for Windows.

Adapun rumus yang digunakan untuk menghitung kevalidan dari suatu instrumen adalah rumus korelasi Pearson Product Moment.

\section{Hasil dan Pembahasan}

Pada awal berdirinya katering Sarahfie, memiliki badan hukum usaha serta terdaftar sebagai perusahaan kemitraan yang bernama CV. Sarahfie Citra Mandiri. Kepemilikan CV. Sarahfie Citra Mandiri dimiliki oleh 2 (dua) orang yakni Ibu Pipit beserta kerabatnya. Seiring berjalan waktu, badan hukum usaha katering Sarahfie berubah menjadi perusahaan perseorangan, dikarenakan kerabatnya meninggal dunia. Badan hukum usaha tersebut masih digunakan hingga saat ini. Oleh karena hal tersebut, pemilik perusahaan belum memperbaharui atau membuat Tanda
Daftar Usah yang baru. Katering Sarahfie telah memiliki nomor pokok wajib pajak dengan nomor 02.568.813.6-424.000 dengan nama perusahaan CV. Sarahfie Citra Mandiri.

Bukti diri pemilik katering Sarahfie saat ini ialah atas nama Pipit Nurindah Sopyati yang beralamatkan di Cipagalo Girang RT 06/07 Kelurahan Margasari Kecamatan Buah Batu. Mengenai perizinan usaha produksi katering Sarahfie telah mendapatkan izin dari kepala RT setempat.

Segmentasi pasar katering Sarahfie berdasarkan geografis ialah masyarakat Jawa Barat dan DKI Jakarta khususnya masyarakat kota Bandung dan sekitarnya. Kemudian berdasarkan demografis ialah usia 17-50 tahun, serta memiliki pekerjaan yang padat. Selanjutnya berdasarkan psikografis dan perilaku ialah ditujukan untuk masyarakat kelas menengah hingga atas dengan gaya hidup serba praktis serta memiliki pengetahuan mengenai katering. Target pasar katering Sarahfie ialah masyarakat kota Bandung dan kota-kota di sekitarnya dengan status sosial menengah keatas.

Posisi pasar katering Sarahfie memposisikan sebagai katering yang siap dalam memenuhi kebutuhan makanan minuman secara massal untuk berbagai acara spesial (special event), seperti resepsi pernikahan, pengajian, syukuran, khitanan, arisan, meeting, dan birthday party.

Berdasarkan seluruh dimensi aspek pemasaran yang dilakukan dengan metode penilaian bauran pemasaran $7 \mathrm{P}$ (Product, Price, Place, Promotion, People, Process, dan Physical Evidence) dengan 38 orang responden penelitian, menyatakan bahwa strategi bauran pemasaran katering Sarahfie secara umum baik.

Aspek keuangan yang dinilai berdasarkan perhitungan arus kas serta perhitungan penilaian investasi yaitu Net Present Value (NPV) memperoleh hasil yang baik. Hasil NPV yakni positif atau 
lebih besar dari nol, sehingga usaha katering dapat dikatakan layak untuk dilanjutkan.

Penentuan lokasi usaha untuk kantor pusat dinilai cukup baik karena strategis dan cukup mudah diakses oleh angkutan umum, sedangkan untuk penentuan lokasi produksi dinilai tidak strategis karena jauh dari pasar utama. Lalu luas produksi serta jumlah karyawan yang dimiliki sudah cukup optimal terhadap jumlah produk yang dihasilkan. Selain itu dalam penentuan tata letak, seluruh ruangan di optimalkan untuk melakukan proses produksi. Namun dalam pemilihan teknologi untuk produksi masih menggunakan peralatan yang sederhana tetapi memiliki kapasitas yang cukup besar, sehingga dapat menghasilkan jumlah yang maksimal. Kemudian cara mengolah makanan dinilai masih kurang baik karena karyawan tidak memiliki pengetahuan mengenai teknis higiene sanitasi yang baik.

Perencanaan SDM yang ditetapkan efisien terbukti dengan penggunaan karyawan yang cukup sedikit serta pengadaan tenaga kerja (karyawan) yang diperoleh cukup ahli dalam bidangnya masing-masing. Namun dalam pemberian kompensasi terhadap karyawan sering terjadi keterlambatan. Selain itu katering Sarahfie tidak memiliki program pengembangan karir untuk karyawannya serta mengenai permasalah yang dialami oleh karyawan, owner kurang meresponnya. Kemudian dalam proses pemeliharaan karyawan, pihak manajemen melakukan agenda liburan bersama, atau melakukan makan bersama.

Selain itu perusahaan tidak memiliki dokumen Prosedur Operasional Standar (Standard Operating Procedure) dan/atau petunjuk pelaksanaan kerja, rencana usaha yang terukur dan terdokumentasi, peraturan perusahaan sesuai dengan ketentuan peraturan perundang-undangan, pelaksanaan program Keselamatan dan Kesehatan Kerja (K3) yang terdokumentasi, sesuai dengan ketentuan peraturan perundangundangan, memiliki sertifikat laik hygiene sanitasi jasa boga, sesuai dengan ketentuan peraturan perundangundangan, pelaksanaan evaluasi kinerja manajemen yang terdokumentasi, memiliki program pelatihan peningkatan kompetensi, karyawan menggunakan pakaian seragam yang bersih dan sopan dengan mencantumkan identitas dan/atau logo perusahaan.

Dampak ekonomi yang ditimbulkan oleh katering Sarahfie sangat positif dirasakan oleh masyarakat, namun berbanding terbalik dengan dampak sosial yang ditimbulkan. Upaya yang dilakukan oleh katering Sarahfie ialah bekerja secara hati-hati dan meminimalkan bunyi yang ditimbulkan dari kegiatan pengolahan makanan.

Terkait pembuangan limbah sisa pengolahan makanan ditempatkan dan dibuang pada tempatnya dengan baik. Hal tersebut tidak merubah atau merusak lingkungan hidup di daerah sekitar perusahaan.

\section{Kesimpulan}

Aspek legalitas berdasarkan penilaian mengenai kelengkapan dan keabsahan dokumen manunjukan hasil yang kurang baik. Terbukti masih terdapat dokumen yang belum terpenuhi serta terdapat dokumen yang belum diperbaharui atau diperbaiki seperti, badan hukum usaha dan tanda daftar perusahaan. Berdasarkan hal tersebut, usaha katering Sarahfie masih dapat dikatakan tidak layak untuk dilanjutkan.

Aspek pasar berdasarkan penilaian mengenai segmentasi pasar (market segmentation), target pasar (market targeting), dan posisi pasar (market positioning) menunjukan hasil yang sangat baik. Terbukti bahwa katering Sarahfie telah menetapkan calon konsumen potensial yang akan membeli produknya. Berdasarkan hal tersebut, 
usaha catering Sarahfie dapat dikatakan layak untuk dilanjutkan.

Aspek pemasaran dengan menggunakan metode penilaian bauran pemasaran (marketing mix 7P) yang dilakukan terhadap konsumen katering Sarahfie menunjukan hasil yang baik. Penilaian tertinggi diperoleh dari segi harga yang ditawarkan, sedangkan penilaian terendah diperoleh dari segi lokasi yang ditetapkan. Dengan demikian bahwa strategi bauran pemasaran yang dilakukan oleh katering sarahfie secara keseluruhan baik, sehingga usaha katering dapat dikatakan layak untuk dilanjutkan.

Aspek keuangan yang dinilai berdasarkan perhitungan arus kas serta perhitungan penilaian investasi yaitu Net Present Value (NPV) memperoleh hasil yang positif. Hasil NPV yakni positif atau lebih besar dari nol, sehingga usaha katering dapat dikatakan layak untuk dilanjutkan.

\section{Aspek teknis/operasi \\ berdasarkan penilaian}

mengenai lokasi usaha, luas produksi, tata letak, pemilihan teknologi, teknis higiene sanitasi, cara pengolahan makanan menunjukan hasil yang kurang baik dalam melakukan proses produksi. Terbukti perusahaan tidak memiliki sertifikasi higiene sanitasi. Berdasarkan hal tersebut, usaha katering Sarahfie dapat dikatakan layak untuk dilanjutkan dengan melakukan beberapa perbaikan.

Aspek manajemen dan organisasi berdasarkan

penilaian

perencanaan SDM, pengadaan tenaga kerja, kompensasi, pengembangan karir, integrasi, serta struktur organisasi menunjukan hasil yang kurang baik. Kemudian perusahaan tidak memiliki dokumen Prosedur Operasional Standar (Standard Operating Procedure) dan/atau petunjuk pelaksanaan kerja, rencana usaha yang terukur dan terdokumentasi, serta peraturan perusahaan sesuai dengan ketentuan peraturan perundangundangan, pelaksanaan program
Keselamatan dan Kesehatan Kerja (K3) yang terdokumentasi, sesuai dengan ketentuan peraturan perundangundangan, memiliki sertifikat laik hygiene sanitasi jasa boga, sesuai dengan ketentuan peraturan perundangundangan, pelaksanaan evaluasi kinerja manajemen yang terdokumentasi, memiliki program pelatihan peningkatan kompetensi, karyawan menggunakan pakaian seragam yang bersih dan sopan dengan mencantumkan identitas dan/atau logo perusahaan. Berdasarkan hal tersebut, usaha catering Sarahfie dapat dikatakan tidak layak untuk dilanjutkan.

Aspek ekonomi/sosial

berdasarkan dampak yang ditimbulkan terhadap ekonomi/sosial dari aktifitas bisnis katering Sarahfie menunjukan hasil yang cukup baik. Dampak ekonomi yang ditimbulkan oleh katering Sarahfie sangat positif dirasakan oleh masyarakat, namun berbanding terbalik dengan dampak sosial yang ditimbulkan. Berdasarkan hal tersebut, usaha katering Sarahfie dapat dikatakan layak untuk dilanjutkan dengan melakukan beberapa perbaikan terhadap dampak sosial yang ditimbulkan.

Aspek lingkungan hidup berdasarkan dampak yang ditimbulkan terhadap lingkungan hidup dari aktifitas bisnis katering Sarahfie menunjukan hasil yang cukup baik. Terkait pembuangan limbah sisa pengolahan makanan ditempatkan dan dibuang pada tempatnya dengan baik. Berdasarkan hal tersebut, usaha katering Sarahfie dapat dikatakan layak untuk dilanjutkan.

Hasil penilaian dari seluruh aspek kelayakan bisnis menunjukan bahwa secara umun bisnis katering Sarahfie dapat dikatakan layak untuk dilanjutkan dan dengan melakukan beberapa perbaikan dari beberapa aspek.

\section{Daftar Pustaka}

Alma, B. (2003). Pemasaran Stratejik Jasa Pendidikan. Bandung: 
Alfabeta

Arikunto, S. (2012). Prosedur Penelitian: Suatu Pendekatan Praktik. Jakarta: Rineka Cipta .(2013).

Prosedur Penelitian, Jakarta: Rineka Cipta.

Bagyono. (2012). Pariwisata \& Perhotelan. Bandung: Alfabeta.

Creswell, J. W. (2016). Research Design, Pendekatan Metode Kualitatif, Kuantitatif, dan Csmpuran. Yogyakarta: Pustaka Pelajar.

Fadiati, A. (2011). Mengelola Usaha Jasa Boga yang Sukses. Bandung: Remaja Rosdakarya Offset.

Fitria, H., \& Kaswara, R. A. (2009). Buku Pintar Berbisnis Katering. Jakarta: Transmedia.

Griffin, W. R., \& Ebert, J. R. (2006). Business. Jakarta: Erlangga.

Henderson, J. C. (2009). Food Tourism Reviewed. Emerald Insight, 317325.

Hendijani, R. B. (2016). Effect of food experience on tourist satisfactioan: the case of Indonesia. Emerald Insight, 272280.

Sumber Undang-Undang:

Penjelasan PP RI No. 50 Tahun 2011 Tentang Rencana Induk Pembangunan Kepariwisataan Nasional tahun 2010-2025

Ibrahim, Y. (2009). Studi Kelayakan Bisnis. Jakarta: Rineka Cipta.

Johan, S. (2011). Studi Kelayakan Pengembangan Bisnis. Yogyakarta: Graha Ilmu.

Jumingan. (2009). Studi Kelayakan Bisnis. Jakarta: Bumi Aksara.

Kasmir, \& Jakfar. (2012). Studi Kelayakan Bisnis. Jakarta: Kencana Prenada Media Grup.

Kotler, P., \& Armstrong, G. (2007). Dasar-dasar Pemasaran. Edisi Bahasa Indonesia. Jakarta: PT. Prehallindo

Kotler, P., \& Armstrong, G. (2012). Prinsip-Prinsip

Pemasaran.
Jakarta: Erlangga.

Kotler, P., \& Keller, K. L. (2009). Manajemen Pemasaran. Jilid I. Edisi ke 13. Jakarta: Erlangga

Kotler, P., \& Keller, K. L. (2016). Marketing Management (Fifteenth Edition). England: Pearson Education Limited.

Lupiyoadi, R. (2013). Manajemen Pemasaran Jasa. Jakarta: Salemba Empat.

Lupiyoadi, R., \& Hamdani, A. (2009). Manajemen Pemasaran Jasa, Edisi 2. Jakarta: Salemba Empat.

Machfoedz, Mahmud. (2010). Komunikasi Pemasaran Modern. Yogyakarta : Cakra Ilmu.

Manullang. (2013). Pengantar Bsinis. Jakarta: Permata Putri Media.

Marpaung, H. (2002). Pengetahuan Kepariwisataan. Bandung: Alfabeta.

Nawawi, H. (2011). Manajemen Sumber Daya Manusia. Yogyakarta: Gadjah Mada University Press.

Pendit, S. N. (2006). Ilmu Pariwisata. Jakarta: PT. Pradya Paramita.

Pitana, I. G., \& Diarta, I. K. (2009). Sumarwan, U. (2011). Perilaku Konsumen, Teori dan Penerapannya dalam Pemasaran. Bogor: Ghalia Indonesia.

Sutrisno, Edy. (2011). Manajemen Sumber Daya Manusia. Jakarta: Kencana.

Tantri, F. (2015). Pengantar Bisnis. Jakarta: PT. Raja Grafindo Persada.

Tjiptono, $\quad$ F. (2008). Strategi Pemasaran Edisi III. Yogyakarta: Andi . (2014). Pemasaran Jasa. Yogyakarta: ANDI.

Peraturan Menteri Pariwisata dan Ekonomi Kreatif Nomor PM.53/HM.001/MPEK/2013

Peraturan Menteri Pariwisata dan Ekonomi Kreatif No.18 Tahun 2014

Peraturan Menteri Kesehatan RI 
No.1096/MENKES/PER/VI/20 11 UU RI No. 10 Tahun 2009 Tentang Kepariwisataan

Purwana, D., \& Hidayat, N. (2016).

Studi Kelayakan Bisnis. Jakarta:

PT RajaGrafindo

Persada.Sugiyono. (2013). Metode

Penelitian Bisnis. Bandung:

Alfabeta.

Raharjani, J. (2005). Analisis FaktorFaktor yang Mempengaruhi Keputusan Peilihan Pasar Swalayan Sebagai tempat berbelanja. jurnal studi manajemen dan organisasi, 3 .

Sugiyono. (2013). Metode Penelitian Bisnis. Bandung: Alfabeta. (2015). Statistika Untuk Penilaian. Bandung: Alfabeta.

Suliyanto. (2010). Studi Kelyakan Bisnis. Yogyakarta: ANDI.

Yusuf, A. M. (2015). Metode Penelitian Kuantitatif, kualitatif \& Penelitian Gabungan. Jakarta: Kencana. 